\title{
The Rise and Fall of "Austro-Eurocommunism". On the "Crisis" within the KPÖ and the Significance of East German Influence in the 1960s
}

\author{
Maximilian GRAF
}

Usually, the dramatic events of 1968 in Czechoslovakia are regarded as the starting point for what became known as "Eurocommunism" in the mid-1970s. However, many of the ideas of reform communism had been developing at least since 1956 and had already become part of the official policy of Western European Communist parties throughout the 1960s. This happened long before Warsaw Pact tanks crushed the "Prague Spring" thereby creating a further challenge to Western communists' solidarity with Moscow. Surprisingly enough, the parties that opted for reform included not only the usually suspect Italian communists but also their Austrian "comrades" who had been one of the most consistently Sovietized parties in Western Europe. How was such a development possible and what were the reactions towards it?

This paper deals with the short period of reform communism in the Austrian Communist Party (KPÖ, Kommunistische Partei Österreichs) in the 1960s, a period that has been labelled respectively "Austro-Eurocommunism" by reformist protagonists and the "crisis of the KPÖ" by more orthodox members of the party. Unsurprisingly, the communist parties of the Socialist Bloc took a negative attitude towards Western attempts at reforming communism, even at the national level. In this case, the East German communists took the lead in fighting the reformist forces within the KPÖ. Therefore, the position and actions of the Socialist Unity Party of Germany (SED, Sozialistische Einheitspartei Deutschlands) will be examined in detail. Hence, even though this paper is based on intense multi-archival research in Austria, Germany and Italy, most of the sources cited originate from the SED. Before going into detail, however, some preliminary comparative remarks on post-war developments in Austria and Germany are necessary.

\section{Postwar Context}

After World War II, Austria and Germany came under quadripartite Allied control and occupation. In the occupation period from 1945 to 1955, the KPÖ was subservient to the Communist Party of the Soviet Union (CPSU) and the Soviet Occupation Forces in Austria. Still, contrary to Eastern European countries exclusively occupied by the Soviet Union and the Soviet-occupied Eastern part of Germany, Austria was not Sovietised. Moreover, contrary to what occurred in the Soviet Zone of Occupation in Germany in 1946, where the SED was established, no forced merger of the Austrian 
Communists and Socialists took place. ${ }^{1}$ Compared to their East German counterparts, the Austrian communists had less support from the Soviets. This unsatisfying fact was recognized by the Austrians via their contacts with East German "comrades". 2 Whereas the Soviets permitted and fostered the division of Germany and the foundation of the German Democratic Republic (GDR), plans by the Austrian communists aimed at a division of Austria were rejected by the CPSU in February 1948. ${ }^{3}$

Publically the KPÖ had welcomed the foundation of the GDR in October 1949 and praised its existence in party media. ${ }^{4}$ Nonetheless, already after the Soviet crackdown on the East German uprising in June 1953 internal criticism about the "whitewashing" of all developments in East Germany arose. The KPÖ leadership, despite its recognition that such events further harmed the image of the KPÖ, defied public opinion and reported positively on East Germany. Hence, it felt that it was not allowed to report in a more negative way than the media of the socialist countries. ${ }^{5}$ The postiveness of the communist media coverage on the Soviet Union and its sphere of influence did everything other than contribute to the party's standing in domestic politics. Lacking the tradition of a workers' party and burdened by its close relationship to the Soviet occupation power, detested by a vast majority of Austrians, the KPÖ never managed to gain a significant voter base. ${ }^{6}$ After the signing of the Austrian State treaty in 1955, through which Austria regained full sovereignty as well as the

1. W. MUELLER, Sowjetische Deutschland- und Österreichpolitik 1941 bis 1955 im Vergleich: Die Frage der staatlichen Einheit und des Friedensvertrages, in: M. GEHLER, I. BÖHLER (eds), Verschiedene europäische Wege im Vergleich. Österreich und die Bundesrepublik Deutschland 1945/49 bis zur Gegenwart. Festschrift für Rolf Steininger zum 65. Geburtstag, Studienverlag, Innsbruck/ Wien, 2007, pp.123-154.

2. ZPA der KPÖ [Zentrales Parteiarchiv der KPÖ, Alfred Klahr Gesellschaft, Wien], Auslandskorrespondenz 1948. Kreilisheim und Knepler an das Sekretariat (im Hause), 12.05.1948: Bericht über die Reise der Genossen Kreilisheim und Knepler zum Ersten Kulturtag der SED in Berlin 05.-08. Mai 1948.

3. W. MUELLER, Die sowjetische Besatzung in Österreich 1945-1955 und ihre politische Mission, Böhlau, Wien, 2005, pp.194-198. For the memo on the conversation of Zhdanov with Koplenig and Fürnberg on 1 February 1948, see IDEM, Die Teilung Österreichs als politische Option für KPÖ und UdSSR 1948, in: Zeitgeschichte, 1(2005), pp.47-54. For a recent summary on the division of Germany, see H.-P. SCHWARZ, The division of Germany 1945-1949, in: M.P. LEFFLER, O.A. WESTAD (eds), The Cambridge History of the Cold War, vol. 1, Origins, pp.133-153.

4. F. WEST, Die Gründung der Deutschen Demokratischen Republik, in: Weg und Ziel, 12(1949), pp. 797-805.

5. ÖGZ [Archiv der Österreichischen Gesellschaft für Zeitgeschichte im Institut für Zeitgeschichte der Universität Wien], Nachlass 40 (Josef Lauscher), DO 173, Mappe 4, fol. 380, Besprechung im Wahlkreis VI über die Ereignisse in den Volksdemokratien am 21. Juli 1953; Ibid., DO 141, Mappe 3, fol. IV.204-214, here p. 211. Die politische Lage und die Aufgaben (Bericht über das letzte Pol.Büro), F. Fürnberg.

6. On the KPÖ in the occupation period, see M. MUGRAUER, Die Politik der KPÖ 1945 bis 1955/56, in: IDEM (ed.), 90 Jahre KPÖ. Studien zur Geschichte der Kommunistischen Partei Österreichs, Alfred Klahr Gesellschaft, Wien, 2009, pp.37-52; F. KELLER, Die KPÖ 1945-1955, in: Jahrbuch für historische Kommunismusforschung 1993, pp.104-121; IDEM, Die KPÖ und die Schauprozesse in Osteuropa 1948 bis 1953, in: W. MADERTHANER, H. SCHAFRANEK, B. UNFRIED (eds), ,Ich habe den Tod verdient “. Schauprozesse und politische Verfolgung in Mittel- und Osteuropa 1945-1956, Verlag f. Gesellschaftskritik, Wien, 1991, pp.199-218. 
disillusioning effects of Nikita Khrushchev's secret speech and his crackdown on the Hungarian uprising in 1956, the KPÖ lost about one third of its membership. ${ }^{7}$ Criticism within the party arose, but these discussions were aborted in favour of the unity of the party. Actually, the developments in the neighbouring "people's democracies" (from then and reinforced after 1956) had made it even harder to promote "socialism" on the domestic scene. Criticism of "real existing socialism" within the party arose. ${ }^{8}$ Understandably, this marked the beginning of slowly growing East German concerns in the second half of the 1950s..$^{9}$ After the construction of the Berlin wall in August 1961, which was defended by the KPÖ chairman Johann Koplenig as an "unavoidable necessity", critiques of developments in the GDR increased within the party, troubling the SED's perception of the Austrian communists even more. ${ }^{10}$ Another disturbing factor in party relations was the KPÖ's refusal to establish an Austrian-East German friendship society, much sought after by the GDR in its struggle for diplomatic recognition. Not surprisingly this was the result of repercussions that the development of the Socialist countries had on the domestic standing of the Austrian communists. ${ }^{11}$ Still, it would be a long time before the crisis in party relations between the KPÖ and the SED escalated.

7. On the Austrian State Treaty, see G. STOURZH, Um Einheit und Freiheit. Staatsvertrag, Neutralität und das Ende der Ost-West-Besetzung Österreichs 1945-1955, $5^{\text {th }}$ rev. ed., Böhlau, Vienna, 2005; A. SUPPAN, G. STOURZH, W. MUELLER (eds), Der Österreichische Staatsvertrag. Internationale Strategie, rechtliche Relevanz, nationale Identität, ÖAW, Vienna, 2005; R. STEININGER, Der Staatvertrag. Österreich im Schatten von deutscher Frage und Kaltem Krieg 1938-1955, Studienverlag, Innsbruck/Wien, 2005.

8. M. MUGRAUER, Zwischen Erschütterung, neuer Offenheit und „Normalisierung: Die KPÖ, der 20. Parteitag der KPdSU und die Ungarn-Krise 1956, in: W. MUELLER, M. PORTMANN (eds), Osteuropa vom Weltkrieg zur Wende, ÖAW, Vienna, 2007, pp.257-297. See also T. KROLL, Kommunistische Intellektuelle in Westeuropa. Frankreich, Österreich, Italien und Großbritannien im Vergleich (1945-1956), Böhlau, Wien, 2007, pp.293-357.

9. For two reports that reached the highest party level of the SED, see PAAA [Politisches Archiv des Auswärtigen Amts, Berlin], MfAA [Ministerium für Auswärtige Angelegenheiten der DDR], A 12822, B1.85-103, Bericht über die Reise der Freundschaftsdelegation des ZK der SED zur KP Österreichs vom 17. bis 23. März 1958. This report was forwarded to the politburo, see SAPMOBArch [Stiftung Archiv der Parteien und Massenorganisation der ehemaligen DDR im Bundesarchiv, Berlin], DY 30/J IV 2/2J/463. For a message that Walter Ulbricht kept in his private papers on the KPÖ, see SAPMO-BArch, NY 4182/1286 (Nachlass Walter Ulbricht), B1. 24-31, Alois Pisnik an Ulbricht, 13.09.1958.

10. ÖGZ, Nachlass 40, DO 141, Mappe 9, fol. IV.379-402, here 391, Gen. J. Koplenig, Die Verschärfung der internationalen Lage und die Auswirkungen auf Österreich, 4. ZK-Plenum, 21. u. 22.09.1961. See also J. EHMER, KPÖ und SED. Ein ambivalentes Verhältnis, in: W. NEUGEBAUER (ed.), Von der Utopie zum Terror. Stalinismus-Analysen (Österreichische Texte zur Gesellschaftskritik 59, Verlag für Gesellschaftskritik, Wien, 1994, pp.171-181, here pp.173-174.

11. SAPMO-BArch, DY 30/IV A 2/20/516, B1. 6-9, Aktennotiz über ein Gespräch mit Heinrich Fritz am 22.04.1963. On the importance of the friendship societies in the GDR's struggle for international recognition, see H. WENTKER, Außenpolitik in engen Grenzen. Die DDR im internationalen System 1949-1989, Oldenbourg, München, 2007, pp.55-56; I. MUTH, Die DDR-Außenpolitik 1949-1972. Inhalte, Strukturen, Mechanismen, Ch. Links, Berlin, 2001, pp.89-90. 


\section{Fighting Ernst Fischer}

The most prominent advocate of this flow of criticism was the intellectual Ernst Fischer. Fischer had been a Stalinist in the first post-war decade. He ruthlessly participated in every reversal of Soviet policy, whether it was the split between Tito and Stalin or the brutal Sovietisation of Eastern Europe. ${ }^{12}$ On the Tito-Stalin-split, Fischer wrote an exemplary Stalinist propaganda play whose only aim was denouncing the Yugoslav leader as a "traitor". It was to be performed first in the Deutsches Theater in East Berlin on 18 July 1950 in view of the cheering SED-elite. Ironically, less than twenty years later, the same elite stigmatized Fischer himself in the same way. Fischer did not officially speak out against the Eastern European show trials or the crackdown on the Hungarian uprising even though it is reported that he had become concerned about the deformities of Socialism. ${ }^{13}$ After the KPÖ had lost its last members of parliament in the general elections of 1959, Fischer retired from official political life and focused on his career as a writer. Nevertheless, what did remain for him at least was cultural-political work. Increasingly, he started criticizing the cultural situation in the Socialist countries.

His remarks at the famous Kafka Conference in Liblice (Czechoslovakia) in 1963, which picked the "estrangement in Socialism" as a central theme, resulted in a heated verbal exchange in the Austrian and East German communist party media. ${ }^{14}$ At this stage, both sides were not interested in a further escalation, and hence, mutual talks by leading representatives from both parties took place. The SED made clear that it disagreed with Fischer's positions and ultimately called for an end to his attacks on the cultural policy of the GDR. In the first half of the 1960s, the Austrians assured their East German "comrades" that they would remonstrate with Fischer about the affair internally. ${ }^{15}$

However, the general debate on culture and politics had continued meanwhile. This debate was fuelled not only by the Kafka-conference but also by Western communists' reactions to Soviet cultural policy, which after the "thaw" of the first Khrushchev years had adopted a harsh anti-intellectual stance by the beginning of the

12. On Fischer, see K. KRÖHNKE, Ernst Fischer oder Die Kunst der Koexistenz, Büchergilde Gutenberg, Frankfurt-a-M., 1994; S. BARYLI, Zwischen Stalin und Kafka. Ernst Fischer von 1945 bis 1972, Studien Verlag/SVK, Bonn, 2008.

13. S. WOLLE, Der große Plan. Alltag und Herrschaft in der DDR (1949-1961), Ch. Links, Berlin, 2013, pp.86-92; F. MUHRI, Kein Ende der Geschichte, Globus, Wien, 1995, pp.107-111.

14. For the papers given at the Kafka-conference, see E. GOLDSTÜCKER, F. KAUTMAN, P. REIMANN (eds), Franz Kafka aus Prager Sicht, Voltaire, Berlin, 1966. See also M. GRAF, M. ROHRWASSER, Die schwierige Beziehung zweier „Bruderparteien“. SED, KPÖ, Ernst Fischer und Franz Kafka, in: J. STAADT (ed.), Schwierige Dreierbeziehung. Österreich und die beiden deutschen Staaten, Peter Lang, Frankfurt-a-M, 2013, pp.137-178, esp. pp.154-163.

15. SAPMO-BArch, DY 30/IV A 2/20/1037, Protokoll über die Aussprache der Genossen Hager, Axen und Florin mit dem Genossen Hexmann, Mitglied des Politbüros der KPÖ, und dem Genossen Scharf, Mitglied des Politbüros der KPÖ und Chefredakteur der Volksstimme am 6. und 7. März 1964, 12.04.1964. 
1960s. ${ }^{16}$ At least since that time it had become clear to the SED that there were some similarities between the Austrian and the Italian Communists. After Italian communist leader Palmiro Togliatti had criticized Soviet cultural policy, Austrian communist Franz Marek contributed to that discussion in the theoretical journal of the KPÖ Weg und Ziel. The SED assumed with great concern that the Italian position had found its echo in the Austrian party. This concern was increased by the reactions of both the Austrian and the Italian parties to Khrushchev's ousting from power in 1964. Both parties were taken by surprise and had not been informed about the domestic and foreign policy reasons for the decision. The Italian party criticized the way the decision had been made and, especially, had been communicated. ${ }^{17}$ Its position was mainly along the lines of what Togliatti had written in his famous "Yalta Memorandum" only a few hours before he had died earlier that year. In his "political testament", Togliatti had summarized his views on the Communist world movement dissenting from the Soviet position - specifically on the question of the necessity of a world conference dealing with Chinese positions. Above all, the weakest Western European parties would have been burdened with this struggle instead of aiming at improving their domestic political influence. In this matter, Togliatti had argued in favour of accepting the political realities of Western Europe, fighting them by winning over a higher percentage of the electorate with more openness toward other political, social and religious groups. ${ }^{18}$ Similar remarks on the ouster of Nikita Khrushchev occurred in the Austrian communist media. The SED assessed it as an attempt to outline a "more autonomous" policy. Obviously, both parties had domestic political reasons for taking such a position. In any event, Khrushchev's removal came at an awkward time for parties facing important regional elections, as it was the case for the Austrian communists. ${ }^{19}$ By the mid-1960s the growing influential reformist flow within the KPÖ was about to be formalized as the party's official line.

At its Nineteenth Party Congress in 1965, the KPÖ adopted a reformist program, which was in large parts written by the reformer Franz Marek and heavily influenced by the ideas of Togliatti. ${ }^{20}$ The "Yalta Memorandum" became the "crucial link" in paving the way to reform. Even though the KPÖ officially rejected Togliatti's doubts about the necessity of an international conference for all communist parties and his

16. V. ZUBOK, Zhivago's Children. The Last Russian Intelligentsia, Harvard University Press, Cambridge, 2009, pp.219-225.

17. SAPMO-BArch, DY 30/IV A 2/20/508, B1. 149-156, esp. B1. 155, Information. Auffassungen leitender Genossen der KP Italiens und der KP Österreichs zu Fragen der Kultur, Berlin, 02.07.1963; B1. 470-472,Kurzinformation über die Stellungnahme der KPI zu den Veränderungen in der Parteiund Regierungsführung der Sowjetunion, 24.10.1964.

18. For the memorandum, see e.g. https://www.marxists.org/archive/togliatti/1964/memorandum.htm (accessed 21 September 2014).

19. SAPMO-BArch, DY 30/IV A 2/20/508, B1. 473-474, Reaktion der KPÖ auf die Veränderungen in der sowjetischen Partei- und Regierungsführung, 24.10.1964.

20. On Marek and the influence of Togliatti's ideas, see L. SPIRA, Ein gescheiterter Versuch. Der Austro-Eurokommunismus, J\&V, München, 1979, pp.22-23; for more recent publications highlighting this assessment, see B. COUDENHOVE-KALERGI, Zuhause ist Überall. Erinnerungen, Czernin, Wien, 2013, pp.185-186; M. GRABER, Franz Marek(1913-1979), in: Mitteilungen der Alfred Klahr Gesellschaft, 2(2013), pp.21 f. 
evaluation of the situation of the small Western European communist parties, what he said showed a possible way for overcoming domestic political isolation. One key element was the party's attitude towards democracy. The changed stance of the KPÖ became a "red rag" for the SED. Talking about the "dictatorship of the proletariat" was no longer sustainable. The reformist and later "Eurocommunist" Western European parties aimed openly at gaining power through fair elections (which in case of the Austrian communists was highly improbable) or gaining domestic political influence by joining forces with other parties. The latter strategy became a highly controversial international topic from the mid-1970s until the mid-1980s, when "Eurocommunism" was talked of not only in Western Europe but also in the United States. ${ }^{21}$ Nonetheless, the roots of this flow originated from the 1960s and not merely at a national level. The Italian origins are doubtless, but in the developing Western European theatre even the small Austrian party aimed at taking the lead.

To what extent the leading reformist circles of the KPÖ had already been thinking in a European dimension became obvious when in May 1966 they hosted a conference of Western European communist parties in Vienna. For Marek, who was the main organizer of this event, it was a logical follow-up to the Brussels Conference of 1965, which had marked a restart for such meetings after initial attempts of the late 1950s. In the Belgian capital, they had dealt with contemporary issues such as the Vietnam War, the question of European security, and solidarity with "persecuted fraternal parties". Marek proposed a continuation of this discussion. Despite being aware of "national characteristics", he aimed at discussing common European challenges in the "capitalist countries". The changes since the interwar period, for example the improved living conditions for the "working class", demanded a new approach to domestic politics. To reform-communists like Marek, it was evident that Socialism had to be attained within the framework of Western European democracy. Therefore, the question of the communists' relationship to "Catholics" and "Socialists" or "Social Democrats" had to be debated anew. ${ }^{22}$ These basic questions were about to become some of the core problems with which "Eurocommunism" dealt in the 1970s. Nonetheless, it seems that in 1966 the time was not yet ripe for such a discussion. The Italian communists appreciated the recently developed awareness, but according

21. N. DÖRR, Der Eurokommunismus als Herausforderung für die europäische Sozialdemokratie. Die Beispiele Frankreich und Italien, in: Perspektiven DS - Zeitschrift für Gesellschaftsanalyse und Reformpolitik, 2(2010), pp.83-102; N. DÖRR, Die Auseinandersetzungen um den Eurokommunismus in der bundesdeutschen Politik 1967-1979, in: Jahrbuch für Historische Kommunismusforschung, 2012, pp.217-232; M. MAYER, «Machterschleichung auf Filzpantoffeln». Die Bundesrepublik, die DDR und die mögliche Regierungsbeteiligung der kommunistischen Parteien in Frankreich und Italien in den Siebzigerjahren, in: Jahrbuch für Historische Kommunismusforschung, 2010, pp.127-141; S. PONS, La politica internazionale di Berlinguer negli anni dell „Unità Nazionale". Eurocomunismo, NATO e URSS (1976-1979), in: A. GIOVAGNOLI, L. TOSI (eds), Un ponte sull'Atlantico. L'alleanza occidentale 1949-1999, Guerini e associati, Milano, 2003, pp. 282-297; A. BROGI, Confronting America: the Cold War between the United States and the Communists in France and Italy, University of North Carolina Press, Chapel Hill, 2011.

22. F. MAREK, Probleme der kommunistischen Parteien Westeuropas, in: Weg und Ziel, 11(1965), pp. 660-672. 
to the report by their representative at the Vienna conference, Ugo Pecchioli, the meeting was not sufficiently prepared. ${ }^{23}$

Marek himself was quite satisfied with the outcome of the conference, even though it had proved impossible to exclude international and foreign policy issues from the conference discussions. ${ }^{24}$ The illegal West German communists had attended the conference. In fulfilling their task as Eastern "agents" within the framework of Western European communism they reported about it to the SED. The chairmen Max Reimann of the West German communists, who lived in exile in East Berlin, regularly attended the politburo sessions of the SED. After returning from Vienna, he used this forum to complain about the negative attitude of Marek toward the GDR. Thereafter, the East German leadership asked the KPÖ for clarification of his statements. An internal SED assessment of the Western communist parties spoke of "bourgeois influences" within the Italian, Austrian, and to a lesser extent French party, which indeed was not yet fully on its way to "Eurocommunism". ${ }^{25}$ However, at this stage no public criticism on the overall policy of these parties arose.

After the Nineteenth Party Congress of the KPÖ in 1965, the attacks by the SED on Fischer actually swelled over to criticisms of official positions of the Austrian party. ${ }^{26}$ Another severe dispute about Fischer occurred in late summer of 1966. Ernst Fischer had participated in a West German television production in which the GDR was heavily criticized. Immediately, the SED started a media campaign against Fischer's statements. ${ }^{27}$ In a further instance, an emergency meeting between the SED's "fire fighter" in inter-party crises, Hermann Axen, and leading politicians of the KPÖ became necessary. Again, the Austrian communists tried to calm the heated situation and promised to deal with Fischer internally. After the Secretary General of the KPÖ Siegfried "Friedl" Fürnberg had proposed to the GDR that they make use of Fischer by letting him perform on East German television, Axen's statement was unambiguous. The diction he took was unusual for a communist of his calibre: "For God's sake, Fischer may corrode capitalism in Austria, but not Socialism in the GDR, which he does not understand anyway". ${ }^{28}$

What had become clear to the SED after this dispute was that among conservative anti-reformist forces within the KPÖ distance to Fischer had grown too. Josef Ehmer,

23. APCI [Archivio del Partito Comunista Italiano, Ugo Pecchioli, Fondazione Gramsci, Rom], Serie: Estero, MF: 537, pp.1016-1094, here pp.1044-1048, Informazione sull'incontro dei partiti comunisti dell'Europa occidentale (Vienna, 9-11 maggio 1966).

24. F. MAREK, Die Wiener Konferenz, in: Weg und Ziel, 7/8(1966), pp.362-368.

25. SAPMO-BArch, DY 30/11774, Notizen zu Wien. Konferenz europ. Bruderparteien, 16.05.1966; DY 30/J IV 2/2/1059, B1.2, Sitzung des Politbüros des Zentralkomitees am 24. Mai 1966; DY 30/11775, Bl. 1-24, Bürgerliche Einflüsse in der kommunistischen Weltbewegung, 29.06.1966.

26. L. SPIRA, op.cit., pp.62 and 66; J. MEISEL, Die Mauer im Kopf. Erinnerungen eines ausgeschlossenen Kommunisten 1945-1970, Verlag für Gesellschaftskritik, Wien 1986, p.181.

27. For a summary, see M. GRAF, M. ROHRWASSER, op.cit., pp.166-172.

28. „Fischer möge doch in Gottes Namen den Kapitalismus in Österreich zersetzen, aber nicht den Sozialismus in der DDR, den er doch ohnehin nicht begreife“. SAPMO-BArch, DY 30/3651 (Büro Ulbricht), Bl. 1-13, Information über ein Gespräch des Genossen Hermann Axen mit dem Genossen Franz Muhri, 30.09.1966. 
an Austrian historian and former member of the KPÖ, supposed almost two decades ago that from this moment on the SED "in secret" had aimed at an expulsion of Fischer from the KPÖ. ${ }^{29}$ Even though there is no document proving this judgment, Ehmer's interpretation is still to the point. The SED sought contact with those KPÖ members, who were against the newly established official reformist stance. Conservative antireformist powers within the KPÖ, like Erwin Scharf (who became the advocate of the East German view), Walter Hollitscher, Friedrich Hexmann, and several others began an intense dialogue with their East German allies, who supported their upcoming standoff with the reformers by continually attacking Fischer and by financing their publications. Another means was direct conversations in the course of mutual visits of delegations. Within the KPÖ the new Chairman elected in 1965, Franz Muhri, tried to mediate between conservatives and reformers in favour of the unity of the party.

In December 1966, a delegation of the KPÖ headed by Muhri paid a visit to the GDR. Not least because of the simmering conflict about Fischer, this "fraternal" encounter attracted attention far beyond the usual level. While Western media (and diplomats) frankly reported about the conflict between the Austrian and the East German communists, both parties tried to avoid such an impression. The First Secretary of the SED Walter Ulbricht was prepared in detail for his conversation with the Austrian delegation. ${ }^{30}$ On the conflict between Fischer and the SED, he took a clear stance. After generally criticizing reformist ideas, he argued that Fischer's public statements were harming the positions of both the Austrian and the West German communists. As long as Fischer's comments do not harm the illegal West German communists' prestige - Ulbricht promised - the SED will stay calm and consider it as an internal affair of the KPÖ. In the same breath, he further stated: "Since Fischer continues his attacks on German soil, the SED has to deliver its opinion in a forthright manner". Muhri answered that the KPÖ opposed some of Fischer's theses, but he did not abstain from declaring that there was also disagreement with some theses propagated by the SED newspaper Neues Deutschland. Again, he tried to mediate by pointing out Fischer's merits for the KPÖ and promising continued internal discussions with Fischer.

Some weeks earlier, Fischer had published his work Art and Coexistence in which he made reference to the Kafka Conference and again criticized the cultural policy of the socialist states. Additionally, it should be mentioned that after several publications in the GDR, Art and Coexistence was his first book to appear in West Germany first. Since Muhri tried to avoid an immediate resurgence of the public clash, he asked the SED not to attack Fischer for this publication. The KPÖ chairman promised a debate on Fischer's writings within the party. Finally, yet most importantly, he asked several times for an understanding of his personal situation because he had only been

29. J. EHMER, op.cit., p.176.

30. For the detailed preparatory papers, see SAPMO-BArch, NY 4182/1286 (Nachlass Walter Ulbricht), B1. 120-191. 
elected Chairman of the KPÖ in 1965 and, therefore, his prime focus was the unity of the party. ${ }^{31}$

\section{Fighting Reform Communism}

It seems that the SED met Muhri's requests. In a politburo session in early January 1967, the SED decided to further intensify contacts with the KPÖ at all levels. No campaign against Fischer's Art and Coexistence was launched; however, the SED was far from being satisfied with the way the KPÖ officially dealt with the content of Fischer's publication. For the SED, the reviews in the KPÖ's party media were not nearly critical enough. Even though the party authorities had approved the reviews, it had become obvious that since 1965 party organs were heavily influenced and perhaps even controlled by the reformist wing of the KPÖ. ${ }^{32}$ This was a fact that gained significance in 1968.

Before turning to the thrilling events resulting from the divergent attitudes toward the "Prague Spring" that finally led to an open outbreak of the crisis within the KPÖ and between the Austrian and East German communists in the late summer of 1968, a closer look will be taken at how the SED tried to influence the struggle between reformers and those opposing reforms within the KPÖ. Despite being far from satisfied with the KPÖ's handling of Fischer, the SED had abstained from officially criticizing Art and Coexistence. However, the SED had paid a lot of attention to the further developments within the KPÖ. When the KPÖ called for a public discussion about "Democracy and Socialism" in 1967 that resulted in controversial statements about the fundamental policy paper written by Marek, the SED analysed it with mistrust. Overall, its perception of the KPÖ had continually worsened. The analysis painted a picture of resignation and disunity, which was regarded as the main reason for not consistently fighting Fischer's positions and having diverged from the path of a "true Marxist-Leninist party". ${ }^{33}$

Because of influential reformers in the politburo of the KPÖ and a so-called "centrist" leadership, the SED felt that it had to rely on those within the KPÖ who openly

31. SAPMO-BArch, DY 30/IV A 2/20/519, B1. 83-100, Bericht über den Besuch einer Delegation der Kommunistischen Partei Österreichs in der Zeit vom 1. bis 7. Dezember 1966. See also E. FISCHER, Kunst und Koexistenz. Beitrag zu einer modernen marxistischen Ästhetik, Rowohlt, Hamburg, 1966, pp.71-74 and 191-193.

32. SAPMO-BArch, DY 30/J IV 2/2/1096, B1. 8, Anlage Nr. 5: B1. 42-44, Sitzung des Politbüros des Zentralkomitees am 31. Januar 1967; DY 30/IV A 2/20/520, B1. 185-188, Information Nr. 16/67 für die Mitglieder und Kandidaten des Politbüros über zwei Besprechungen des Buches von Ernst Fischer, 20.03.1967.

33. SAPMO-BArch, DY 30/IV A 2/20/521, B1. 287-294, Information der Abteilung für Internationale Verbindungen; Betr.: Öffentliche Debatte der Kommunistischen Partei Österreichs zu Fragen, Demokratie und Sozialismus, 29.11.1967; B1. 295-300, Information über die Plenartagung des ZK der KPÖ am 26. und 27. Oktober 1967, 14.12.1967. 
opposed the reformist course. The KPÖ's chairman, Franz Muhri, was regarded as one of those "centrists", who despite apparent disunity acted in favour of the unity of the party by mediating between the antagonist groups.

The most striking example of East German support for the opponents of reform in the KPÖ occurred in the spring of 1968. Erwin Scharf had written an examination of Fischer's Art and Coexistence from an anti-reformist point of view. The KPÖ's politburo had rejected a publication in the party's publishing house "Globus". Only an eventual internal distribution to the members of the central committee was regarded as feasible. Upon hearing this, Scharf asked for support from East Berlin. After the Department for International Affairs of the Central Committee of the SED had studied his writings, it was decided that a publication for the GDR-market was inappropriate because its contents did not meet the requirements of the SED. Instead, they offered to produce a small edition for distribution in Austria only. This procedure was agreed upon in June 1968 when Scharf paid another visit to the GDR. In the course of his visits, he always informed his East German comrades about the internal proceedings of the KPÖ. ${ }^{34}$ His work Lob der Ideologie appeared in the autumn of 1968 - when things had already changed significantly. ${ }^{35}$

Within the leading circles of the KPÖ in the spring of 1968, conflicts had increased further. While the reformers and to some extent, those who remained in-between the antagonist groups had welcomed the developments in Czechoslovakia, the anti-reformist forces heavily opposed them. Since the reformers held strong positions in the politburo and in the party media, the KPÖ publicly welcomed "Socialism with a human face". Internally conflicts about the appraisal of the reforms of the "Prague Spring" were aggravated. ${ }^{36}$

The SED, as many scholarly studies have shown, openly opposed the "Prague Spring" and especially Walter Ulbricht supported and fostered the idea of an inter-

34. SAPMO-BArch, DY 30/IV A 2/20/1037, Aussprache der Genossen Honecker und Axen mit dem Leiter der österreichischen Delegation, Gen. Erwin Scharf [...], am 4. März 1968; DY 30/IV A 2/20/517, B1. 137-138, Axen to Markowski, 29.03.1968; NY 4182/1286 (Nachlass Walter Ulbricht), B1. 242-247, Bericht über den Besuch des Genossen Erwin Scharf [...] in der DDR (13. bis 16.06.1968), 26.06.1968; B1. 248-251, Gesprächsvermerk über ein Gespräch des Genossen Hermann Axen, Kandidat des Politbüros und Sekretär des ZK der SED, mit Genossen Erwin Scharf [...], am 14.06.1968, 26.06.1968.

35. E. SCHARF, Lob der Ideologie. Den Marxismus nicht anpassen sondern weiterentwickeln, Verlag d. Wissenschaften, Berlin (Ost), 1968. For the personal account by Scharf, see: E. SCHARF, Ich hab's gewagt mit Sinnen... Entscheidungen im antifaschistischen Widerstand. Erlebnisse in der politischen Konfrontation, Globus, Wien, 1988, pp.251-261.

36. M. MUGRAUER, Der ,Prager Frühling “ und die Parteikrise der KPÖ, in: S. KARNER, N. TOMILINA, A. TSCHUBARJAN, et al., Prager Frühling. Das internationale Krisenjahr 1968, vol. 1: Beiträge, Studienverlag, Wien, 2008, pp.1043-1061, here: p.1046. 
vention in Czechoslovakia. ${ }^{37}$ Due to constant denunciation reports by Erwin Scharf and in spring and summer 1968, especially by Walter Hollitscher, the SED was well informed and - not surprisingly - highly concerned about the situation within the KPÖ. ${ }^{38}$ Understandably, East Berlin's focus was on the developments in Czechoslovakia and on finding a possibility to end them. What Ulbricht had desired came to pass on 21 August 1968, when Soviet-led Warsaw Pact forces invaded Czechoslovakia.

Already on 21 August 1968, the KPÖ had officially condemned the crackdown on the "Prague Spring" by the Warsaw Pact powers. This led to an open outbreak of the conflict between the KPÖ and the Socialist Bloc. Fischer spoke of "tank communism" and publicly called for a split with the Soviet Union in the case of a lasting occupation of Czechoslovakia. The condemnation of the invasion was a result of the composition of the KPÖ leadership and the wait-and-see attitude adopted by the antireformists. ${ }^{39}$ The SED was enraged and convinced that within the KPÖ the reformers had entirely taken over. Once again, it was Fischer who was attacked. Now, the SED publicly called for an expulsion of Fischer from the KPÖ. ${ }^{40}$ In fact, Fischer was the target not only of East German enragement but his statements also contributed to insurmountable clashes within the KPÖ. To many ordinary party members, his statements had gone too far. After the invasion of Czechoslovakia, the KPÖ, with the aim of discussing the consequences on a multilateral level, had called for a conference of Western European parties. The idea, however, was finally rejected by the Western "fraternal parties". The main reason was that the CPSU heavily opposed such a conference and was pressing the French and Italian communists not to take part in such

37. On the SED and "Prague Spring", see L. PRIESS, V. KURAL, M. WILKE, Die SED und der „Prager Frühling “ 1968. Politik gegen einen ,, Sozialismus mit menschlichem Antlitz “, AkademieVerlag, Berlin, 1996; R. WENZKE, Die NVA und der Prager Frühling. Die Rolle Ulbrichts und der DDR-Streitkräfte bei der Niederschlagung der tschechoslowakischen Reformbewegung, Ch. Links, Berlin, 1995. On Ulbrichts position within the context of the Warsaw Pact meetings, see J. PAUER, Prag 1968. Der Einmarsch des Warschauer Paktes. Hintergründe - Planung - Durchführung, Ed. Temmen, Bremen, 1995; on the situation in the GDR in 1968 see S. WOLLE, Der Traum von der Revolte. Die DDR 1968, Ch. Links, Berlin, 2008; for a short summary on the GDR's perception of Czechoslovakia throughout the 1960s, see M. GRAF, Die Entwicklungen in der Tschechoslowakei in den 1960er Jahren aus Sicht der DDR, in: F. KASTNER, B. VESELÁ, J. JAROŠ, C. KNOCHE (eds), ,,Prager Frühling “ und „Ära Kreisky“. Zwischen Reformwillen und Reformverwirklichung. Untersuchungen zu den europäischen Nachbarn Tschechoslowakei und Österreich, Iuvenilia Territorialia, Praha, 2009, pp.19-40.

38. SAPMO-BArch, DY 30/IV A 2/20/1037, Vermerk über ein Gespräch der Genossen Kurt Rätz und Hans Jungblut mit dem österreichischen Genossen Prof. Dr. Walter Hollitzscher [sic!], 28.05.1968; DY 30/IV A 2/20/518, B1. 65, Gespräch mit Gen. Prof. Walter Hollitscher, Mitglied des ZK der KPÖ, 05.08.1968.

39. For interpretations on the bringing about of the decision by the KPÖ, see L. SPIRA, op.cit, pp.89-99; M. MUGRAUER, op.cit., pp.1043-1061, here pp.1046-1049. SAPMO-BArch, DY 30/IV A 2/20/522, Einschätzung zur Reaktion der KPÖ auf die Intervention, 02.09.1968.

40. For example, see Neues Deutschland, 04 and 13.09.1968. 
an event. ${ }^{41}$ Although both the French and the Italian parties openly opposed the intervention, the time was not yet ripe for a joint action by the Western European communists. Being the most influential communist parties in the West, they avoided siding with extremely small "fraternal parties" from within whose ranks "comrades" were even calling for a split with the Soviet Union.

In early December 1968, a delegation of leading Austrian communists paid a visit to the Soviet Union. The main reason for the invitation by the CPSU was the KPÖ's condemnation of the invasion of Czechoslovakia. No joint statement on the intervention was agreed upon - a fact that went unmentioned in the joint communiqué. This caused heated debates within the political leadership of the KPÖ. For many reformers, the text of the communiqué was not an ideal compromise, despite which - at least officially - the party had not revised its standpoint. Fischer called it a break from the party's position and a blow to the party's credibility. Hence, the party media in addition to the communique published an interview with Muhri in which he confirmed that the KPÖ's position had not changed. In retrospect, some reformers spoke of the "turnaround" in Moscow. New archival evidence suggests that this interpretation is correct. Vadim Sagladin, Deputy Head of the International Department of the Central Committee of the CPSU informed the GDR Embassy in Moscow that from the Soviet perspective, Muhri's attitude in Moscow had been far more "positive" than the contents of his interview back home. ${ }^{42}$ In any case, the Moscow visit was a harbinger of the upcoming "normalization" of the KPÖ.

\section{"Normalization"}

The SED, actually, was in denial about the true situation within the KPÖ. Soon, it turned out, strong groups within the KPÖ opposed the official stance taken by the party leadership. Despite continuous information from anti-reformist members of the KPÖ about their plans to revise the position of the party, the SED had almost no glimmer of hope for the future development of the KPÖ by the end of $1968 .{ }^{43}$

41. RGANI, Fond 3, opis' 72, delo 210, Protokoll der Sitzung des Politbüros der KPdSU vom 11. Oktober 1968, Beschluss Nr. 23; Beilage 2: Schreiben an den sowjetischen Botschafter in Paris. Kopie im Archiv des Ludwig-Boltzmann-Instituts für Kriegsfolgenforschung, Graz.

42. SAPMO-BArch, DY 30/IV A 2/20/163, B1. 266-270, Vermerk über ein Gespräch mit Sagladin [signed Bittner], 20.12.1968.

43. SAPMO-BArch, DY 30/IV A 2/20/517, Bl. 175-178, Vermerk [of Waschewski] über ein Gespräch mit dem Genossen Fritz im Zentralkomitee der KPÖ am 17. September 1968, 18.09.1968; DY 30/ IV A 2/20/1037, Aktenvermerk über eine Aussprache des Gen. Markowski mit dem Mitglied des ZK der KP Österreichs, Gen. Zucker-Schilling, am 9. Oktober 1968, 11.10.1968; DY 30/ IV A 2/20/517, Bl. 190-193; Vermerk über ein Gespräch mit dem Genossen Friedrich Hexmann, Mitglied des ZK der KP Österreichs am 31. Oktober 1968, 08.11.1968; DY 30/IV A 2/20/520, B1. 193-197, Einschätzung zu KPÖ Dezember 1968. 
Immediately after the invasion, the conservatives began preparing for their final battle against the reformers, which they intended to initiate at the Twentieth Party Congress in January 1969. One of their paramount goals was to get rid of Fischer. Despite knowledge of the conservatives' plans, the SED did not expect a breakthrough in $1969 .{ }^{44}$ Even though major disputes on fundamental questions concerning the current state and future of the party persisted, personal matters were the central issue of the Party Congress. The anti-reformist forces had carefully prepared to topple various reformers from the party's central committee. To prevent a split within the KPÖ, Muhri together with Fürnberg, pressed for time, pushed for an en-bloc re-election; and finally most of the reformers maintained their positions. The turbulent Party Congress, due to the efforts of the so-called "centrists", Muhri and Fürnberg, who opted for unity within the party, ostensibly ended with a compromise. Still, this setback for the anti-reformist forces constituted only a short adjournment of the innerparty struggle. The problems and antagonisms were now apparent to all party-members and the course of the Party Congress already foreshadowed future developments. ${ }^{45}$ Nevertheless, the SED report on the Party Congress assumed that the reformers had entirely taken over. A first report by the SED-delegate Hermann Matern was even flown out of Vienna in an otherwise empty plane and directly delivered to Walter Ulbricht. Matern had completely misperceived and misinterpreted the situation within the KPÖ. In his report to the politburo, he claimed that the Party Congress had been a victory for the "revisionist forces around Marek". ${ }^{46}$

The opposite was the case. Despite still being part of the leadership, the reformers began to retire from party life. Marek stopped attending politburo sessions. Even though it took two attempts, within less than a year, Fischer had been expelled from the KPÖ. The final decision resulted in a severe clash between the remaining reformist supporters, who continued to protest the expulsion, and the anti-reformists who continued to gain ground in the inner-party struggle. The last reformers and their most prominent remaining advocate Marek were also expelled or quit the party severely disappointed. ${ }^{47}$

44. SAPMO-BArch, DY 30/IV A 2/20/517, Bl. 190-193, Vermerk über ein Gespräch mit dem Genossen Friedrich Hexmann, [...] am 31. Oktober 1968, 08.11.1968; B1. 208-211, Information über Besprechungen anläßlich der Trauerfeier für Genossen Koplenig in Wien; L. SPIRA, op.cit., pp. 128-132.

45. On the twentieth party congress of the KPÖ, see L. SPIRA, op.cit., pp.137-157; M. MUGRAUER, „, Oft setzte man sich über vernünftige Argumente hinweg... “. Die krisenhafte Entwicklung der KPÖ in den Jahren 1968 bis 1971, in: IDEM (ed.), 90 Jahre KPÖ. Studien zur Geschichte der Kommunistischen Partei Österreichs, Verlag der Alfred Klahr Gesellschaft, Wien, 2009, pp.261-318, here pp.276-280.

46. SAPMO-BArch, NY 4182/1286 (Nachlass Walter Ulbricht), Bl. 218-220, Matern to Ulbricht, 06.01.1969; DY 30/J IV 2/2A/1350, B1. 50-79, Sitzung des Politbüros des Zentralkomitees am 14. Januar 1969; DY 30/IV A 2/20/1040, B1. 1-21, Bericht von Hermann Matern über die Teilnahme einer Delegation des ZK der SED am XX. Parteitag der KPÖ vom 3. bis 6. Januar 1969 in Wien, 13.01.1969.

47. For details, see L. SPIRA, op.cit., pp.162-212. 
With satisfaction, the SED noticed that the conservatives had managed to expel Fischer and crowd most of the reformers out of the party in a little more than a year. However, the (extraordinary) Twenty-First Party Congress of the KPÖ in 1970 was still regarded as "normalization" with a stigma because no resolution on a revision of the party's position towards the invasion of 1968 had been adopted. The SED spoke of Muhri's Czechoslovakian "trauma". ${ }^{48}$ Hence, the KPÖ was regarded with mistrust until it took back its condemnation of the 1968 invasion in 1971 and the central committee decided that the intervention needed to be regarded as "a bitter necessity". 49

Thereafter, the KPÖ returned to a completely Muscovite stance. Henceforth, KPÖ and SED re-established close ties. ${ }^{50}$ On "Eurocommunism", which at that time was on the rise, they took nearly the same stance. Both parties truly opposed the politics of the Italian, French and Spanish communists in the 1970s. Those who had crowded out the KPÖ reformers still feared the possible influence or return of reformist ideas successfully propagated by the bigger Western European parties. The SED under the leadership of Erich Honecker (who superseded the disempowered Ulbricht in 1971), however, developed a more pragmatic approach. Despite rejecting "Eurocommunism", dialogue with "fraternal parties" in the West was maintained and was aimed at overcoming the reformist era. ${ }^{51}$

When Mikhail Gorbachev introduced his reforms in the second half of the 1980s, both sides were actually anxious about further developments in the Soviet Union and possible repercussions for the Socialist Bloc and in the domestic arena. The institutionalized and personalized solidarity with the Soviet Union hindered them from openly criticizing glasnost and perestroika right from the start. It was only at the end of the 1980s that the SED started openly criticizing Gorbachev's politics, thus avoiding any repercussions for the GDR. The KPÖ hung back with official criticism until the revolutions of 1989 had almost entirely and definitively ended communist rule in

48. SAPMO-BArch, DY 30/IV A 2/20/1003, B1. 85-90, Information Nr. 2/70 für die Mitglieder und Kandidaten des Politbüros, 12.01.1970; DY 30/IV A 2/20/521, Bl. 183-195, Bericht über den XXI. (außerordentlichen) Parteitag der Kommunistischen Partei Österreichs in Wien [1970].

49. M. MUGRAUER, op.cit., pp.261-318, here p.299.

50. N. DÖRR, Die Beziehungen zwischen der SED und den kommunistischen Parteien West- und Südeuropas. Handlungsfelder, Akteure und Probleme, in: A. BAUERKÄMPER, F. DI PALMA (eds), Bruderparteien jenseits des Eisernen Vorhangs. Die Beziehungen der SED zu den kommunistischen Parteien West- und Südeuropas (1968-1989), Ch. Links, Berlin, 2011, pp.48-65, here: p.60-61.

51. On the SED and „Eurocommunism“ in general, see A. BAUERKÄMPER, F. DI PALMA (eds), op.cit.; L. FASANARO, Eurocommunism. An East German perspective, in: L. NUTI (ed.), The Crisis of Détente in Europe. From Helsinki to Gorbachev, 1975-1985, Routledge, London, 2009, pp.244-255; for a contemporaneous KPÖ-publication on „Eurocommunism“, see F. MUHRI, E. SCHARF, E. WIMMER (eds), Eurokommunismus? Eine Sammlung von Stellungnahmen, KPÖ, Wien, 1978. 
East-Central Europe. ${ }^{52}$ The fall of the Berlin Wall 1989 and German reunification in 1990, were a "shock" to the KPÖ, not least, because of its financial dependence on the SED. ${ }^{53}$ The end of communism in Europe, however, not only led to a further decline of the KPÖ but also brought back the internal divergences of the 1960s. The already dwarfish party lost some further members disappointed by the first revelations that came after the revolutions of 1989. Its first post-1989 leadership retired only a little more than a year after its election at the Twenty-Seventh Party Congress in January 1990. The main struggle was about the future orientation of the KPÖ. Until today, there has been no true consensus within the party about whether the KPÖ should be a classical "revolutionary party" or if it should transform itself into a more open party of the left. ${ }^{54}$ At the European level, the KPÖ is a founding member and active participant in the European Left. At home, there is no consensus about the party's European policy. ${ }^{55}$

\section{Conclusions}

It is no surprise that the SED during the Ulbricht era opposed any reformist stance taken by a communist party, whether in the East or in the West. Whenever other communists started to criticize the situation in the GDR, a conflict seemed unavoidable. In the case of the Austrian communists, reformist thoughts and politics made the SED openly attack Fischer and the KPÖ. One reason why this was done so fiercely was because of the common German language. Fischer's public statements in West Germany, especially those in which he frequently criticized the GDR, were suitable for further damaging the image of the illegal West German Communists and the GDR in West German society. Moreover, the GDR was not able to entirely shut out Western media. To what extent its leadership feared the influence of reformist ideas propagated by Austrian communists is not easy to prove on the basis of available sources,

52. SAPMO-BArch, DY 30/J IV 2/2A/3085, B1. 136-160, Niederschrift über das Gespräch des Generalsekretärs des ZK der SED, Genossen Erich Honecker, mit dem Vorsitzenden der Kommunistischen Partei Österreichs, Genossen Franz Muhri, am 30. November 1987. On the published position towards Perestroika in Weg und Ziel, see P. WIMMER, Die Rezeption der Ideologie der Perestroika durch die KPÖ von 1985 bis 1990. Anhand ,Weg und Ziel, der „,Monatsschrift für Theorie und Praxis des Marxismus-Leninismus “, Dissertation University of Vienna, 2003.

53. Archiv des Parteivorstands Die Linke, Zur Reise von Gregor Gysi in die Republik Österreich (5. bis 8. Juni 1990). See also M. GRAF, Parteifinanzierung oder Devisenerwirtschaftung. Zu den Wirtschaftsbeziehungen von KPÖ und SED, 1946-1989, in: Jahrbuch für historische Kommunismusforschung, 2014, pp.229-247, here: pp.239-246.

54. P. WIMMER, op.cit., pp.257-266 and 270-271; I. BRICKNER, C.M. SCHMIDT, Wie die „Kummerln “ ̈̈berlebten, in: Der Standard, 06-07.09.2014, p.20.

55. M. GRAF, Die KPÖ und Europa. Internationale Stellung und Europapolitik einer Kleinpartei (1945-heute), in: F. DI PALMA, W. MUELLER (eds), Kommunismus und Europa: Europavorstellungen und -politik europäischer kommunistischer Parteien im Kalten Krieg, Ferdinand Schöningh, Paderborn, forthcoming 2015. 
but the SED's reaction to the "Prague Spring" provides us with unambiguous insights into its general attitude towards reform communism in the late Ulbricht era. ${ }^{56}$

From what we now know, it is impossible to prove the extent to which financial matters influenced the crisis in party relations between KPÖ and SED in the 1960s. A closer analysis of economic relations between the two parties leads us to the conclusion that the financial dependence of the Austrian communists resulted from growing bilateral trade between Austria and the GDR in the 1970s and 1980s. ${ }^{57}$ Still, besides propaganda the SED tried to place pressure on the Austrian communists by stopping the import of KPÖ publications.

The SED's open engagement in favour of the KPÖ's anti-reform forces, who became advocates of the SED's position, and the numerous East German attacks on Ernst Fischer created a complicated situation for the Austrian party. The settlement of the party crisis of the KPÖ by returning to an entirely Muscovite stance and the expulsion of the reformers were much more due to the situation within the KPÖ. The "centrist" leadership hoped to avoid a definitive split with Moscow and the majority of the party members (however instrumentalized they were by the anti-reformist activists) did not accept the most extreme positions taken by the reformers. In the end, their struggle for some sort of reformed communism (similar to the "Eurocommunist" developments of the 1970s), simply lacked a basis. Those who might have backed the reformers had left the party a dozen years earlier. New archival evidence suggests without much doubt that the influence of the CPSU in 1968 had shown a stronger effect than preceding efforts by the SED. The same holds true for Moscow's successful prevention of joint (re)action by the Western communist parties after the crackdown on "Prague Spring". The East German party - albeit permanently well informed - was everything but certain about the future development within the KPÖ. On the contrary, even after the conservatives had almost irrevocably won the innerparty struggle, the SED had the impression that the reformers had taken over. The condemnation of the invasion of 1968 remained a point of conflict until it was finally rescinded in 1971. Anti-reformist Austrian communists could rely on East German support, but the die had been cast within the KPÖ.

56. The East German State Security used Fischer's Art and Coexistence as training material for its cadres/agents. Cf. A. SCHMOLE, “Operationsgebiet” Österreich, in: J. STAADT (ed.), Schwierige Dreierbeziehung. Österreich und die beiden deutschen Staaten, Peter Lang, Frankfurt-a-M, 2013, pp.179-225, esp. pp.222-225.

57. M. GRAF, op.cit., pp.229-247, here pp.239-246. 